Tips om medisinsk litteratur, andre bøker, filmer og elektroniske medier som bør anmeldes, sendes tidsskriftet@legeforeningen.no

\section{Nyttige innspill til håndtering av et krevende arbeidsliv}

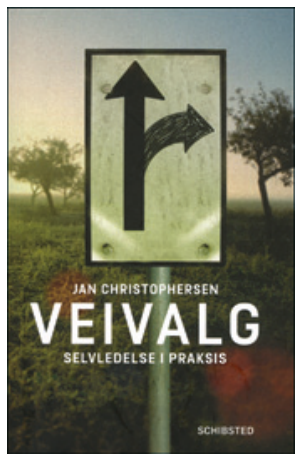

\section{Jan Christophersen}

Veivalg

Selvledelse i praksis. 314 s, ill.

Oslo: Schibsted Forlag, 2012. Pris NOK 299

ISBN 978-82-516-5762-4

Forfatteren er arbeids- og organisasjonspsykolog med lang erfaring fra næringslivet. Han er også en erfaren fjellklatrer og ekspedisjonsleder, noe han passer på å minne leseren om flere steder. Ideen til å skrive tok form da forfatteren besvarte spørsmål fra leserne i A-magasinets spalte Veivalg. Målgruppen er et bredt publikum, og teksten er ført $i$ et lett tilgjengelig språk. Forfatteren har valgt å tone ned referanser, men har inkludert en litteraturliste.

Formålet, utover å formidle kunnskap, er ifølge forfatteren å oppfordre til å forankre livet i sunne dyder og utvise mer ansvar og treningsvilje for å virkeliggjøre de menneskene vi ønsker å fremstå som. Boken hører hjemme i sjangeren selvutviklingslitteratur og er teoretisk inspirert av positiv psykologi. Innledningsvis presenteres positiv psykologi som et fruktbart alternativ til «terapismen», der mennesket fremstilles som offer for sin egen historie, og «økonomismen», der mennesket fremstår som et asosialt og egoistisk vesen. Positiv psykologi er opptatt av å redusere negativt «selvsnakk» som kan begrense vårt handlingsrom, og å se etter muligheter fremfor begrensninger.

I andre kapittel presenteres selvledelse som beslutningsstøtte i valgsituasjoner. Selvledelse handler om å ta ansvar i valgsituasjoner med bevisst hensyntaken til hvem vi ønsker å være, og de verdiene vi setter høyt. Forfatteren presenterer Seligmans modell for effektiv imøtegåelse av negative selvinstrukser og en egenutviklet arbeidsmodell for endring av selvinstrukser. Verdier, vilje, valg og velvilje er forfatterens veivisere til hjelp for å gjøre gode prioriteringer. Han viser til en rekke eksempler og har lagt inn øvelser i selvledelse for leseren.

Nesten halvparten av boken består av lesernes spørsmål og forfatterens svar i spalten Veivalg i A-magasinet. Spennet i tematikk er stort, fra samlivsproblemer til barneoppdragelse og umulige sjefer. Denne delen ga meg lite. Jeg forstår heller ikke hvorfor forfatteren velger å posere som ekspedisjonsleder, rypejeger i 24 kuldegrader og bestiger av Mount Everest.

Boken er preget av forfatterens erfaring som arbeids- og organisasjonspsykolog i næringslivet, og holder seg innenfor normalpsykologien. Fremstillingene er verken beregnet for, eller egnet til, bruk i behandlingen av psykisk lidelse, selv om perspektiver fra positiv psykologi også kan være nyttige i pasientmøtet. For Tidsskriftets lesere kan den første delen gi nyttige innspill til å håndtere et krevende arbeidsliv og gjøre gode prioriteringer mellom arbeidsliv og privatliv.

\section{En meget leseverdig lærebok om hjerneslag}

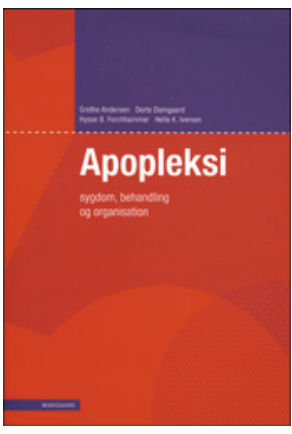

\author{
Grethe Andersen, Dorte Damgaard, \\ Hysse B. Forchhammer et al. \\ Apopleksi
}

Sygdom, behandling og organisation. 357 s, tab, ill. København: Munksgaard Danmark, 2012. Pris DKK 298

ISBN 978-87-628-0960-4

Det er bare å gratulere det danske hjerneslagmiljøet med Apopleksi - sygdom, behandling og organisation. Dette er første utgave av en bredt anlagt og meget leseverdig lærebok om hjerneslag. Den har både leger, sykepleiere og annet fagpersonell som målgruppe. De fire kvinnelige redaktørene har med seg over 60 medforfattere, flest leger, men også sykepleiere, fysioterapeuter, ergoterapeuter og nevropsykologer gir viktige bidrag.

I til sammen 18 kapitler får leseren en meget fin innføring i ulike emner som epidemiologi, cerebral anatomi, patofysiologi, slagsymptomer, radiologi, akutt behandling, sekundærprofylakse, slag hos barn og unge, rehabilitering og psykososiale forhold. Kapitlene kan leses hver for seg, og boken er veldig godt egnet som oppslagsbok i det daglige arbeidet med hjerneslagpasienter. Faktabokser hjelper leseren til å få med seg kjernebudskapet, og de relativt få, men oppdaterte, referansene er godt selekterte. For en norsk leser er det danske språket ingen hindring. Layouten er smakfull, og papir, bilder og figurer er av god kvalitet.

Hjernen er vårt viktigste organ, og ved akutt sirkulasjonsforstyrrelse i hjernen er tid den helt avgjørende faktoren. Våre danske kolleger har virkelig forstått at hjerneslagbehandling krever god overordnet organisering og en grad av styrt sentralisering for å lykkes. Hjerneslag blir «tatt på alvor» i Danmark, og resultatene av dette viser seg raskt. Alle regioner i Danmark har nå minst ett definert «trombolysesenter» der hjerneslagpasienter mottas av spesialutdannede leger og sykepleiere på døgnbasis. I tillegg bygges det opp høyspesialiserte, akademiske slagsentra i Odense, Århus og København som tilbyr nevrointervensjon med trombektomi for selekterte pasienter.

Hjerneslag rammer rundt 15000 nordmenn hvert år. Det norske helsevesenet makter i dag ikke å gi alle slagpasienter et faglig god nok tilbud. Norske helseledere burde lese denne boken og snarest mulig reise på hjerneslagstudietur til vårt naboland i sør.

\author{
Christian Georg Lund \\ Nevrologisk avdeling \\ Klinikk for kirurgi og nevrofag \\ Oslo universitetssykehus, Rikshospitalet
}

